\title{
KONTRIBUSI LIMBAH DOMESTIK PENDUDUK DI SEKITAR SUNGAI BIKNOI TERHADAP KUALITAS AIR BENDUNGAN BIKNOI SEBAGAI SUMBER BAKUAIR MINUM SERTA UPAYA PENANGANANNYA
}

\author{
Maya Roman $^{1)^{*}}$, Fransiskus Kia Duan ${ }^{1,2)}$, Suwari $^{(1,3)}$ \\ ${ }^{1)}$ Program Magister Ilmu Lingkungan,Universitas NusaCendana, Kupang, \\ Jl. Adisucipto Penfui Kupang \\ ${ }^{2}$ Fakultas Sains dan Teknik,Universitas Nusa Cendana, Kupang Jl. Adisucipto Penfui Kupang \\ ${ }^{3)}$ Fakultas Sains dan Teknik,Universitas Nusa Cendana, Kupang Jl. Adisucipto Penfui Kupang \\ "Email : mayaroman28@gmail.com
}

\begin{abstract}
Biknoi River is potential to be polluted by domestic cesspool because it crosses settlement area. It is important to be paid more attention because the water from Biknoi River is used as the basic source of Municipal Waterworks (PDAM) of Kupang town. The aims of the research are identifying the society along the riversides' habitual in throwing out the domestic cesspool which potential to reduce the quality of the water in that river, evaluating the waters' quality, knowing the contribution of the society's domestic cesspool towards the water's quality in Biknoi dam, knowing the level of water pollution by using Pollution Index method and knowing the effort for solving this problem.This research combined physical research and social research. Physical research was done by chemistry analysis for the sample of water, while the social research was done by having an interview which used questionnaire. The result of this research showed that there was a strong relationship between the society's habitual with the reduce of the water's quality of Biknoi River. The reduce of the water's quality showed by the result of pollution enumeration index i.e. medium pollution category. The biggest pollution is COD i.e. 28.996 ton / month. The effort to solve this problem is by making the society to be aware, cesspool management, aware of rules, critical area rehabilitation, real action, controlling and layout.
\end{abstract}

Keywords: Biknoi River; domestic cesspool; water quality;pollution index; AHP

\begin{abstract}
Abstrak
Sungai Biknoi berpotensi tercemar oleh limbah domestik karena melintasi kawasan permukiman. Hal ini penting untuk mendapat perhatian lebih karena air dari Sungai Biknoi digunakan sebagai sumber Perusahaan Daerah Air (PDAM) kota Kupang. Tujuan dari penelitian ini adalah mengidentifikasi kebiasaan masyarakat di sepanjang aliran sungai membuang limbah domestik yang berpotensi menurunkan kualitas air di sungai, evaluasi kualitas air, mengetahui kontribusi limbah domestik masyarakat terhadap kualitas air di bendungan Sungai Biknoi, mengetahui tingkat pencemaran air dengan menggunakan metode Indeks pencemaran dan mengetahui upaya untuk memecahkan masalah tersebut.Penelitian ini menggabungkan penelitian fisik dan penelitian sosial. Penelitian fisik dilakukan dengan analisis kimia untuk sampel air, sedangkan penelitian sosial dilakukan dengan melakukan wawancara yang menggunakan kuesioner. Hasil penelitian ini menunjukkan bahwa ada hubungan yang kuat antara kebiasaan masyarakat dengan menurunnya kualitas air dari Sungai Biknoi . Penurunan kualitas air ditunjukkan dengan hasil indeks polusi enumerasi yaitu polusi kategori menengah. Polusi terbesar adalah COD yaitu 28,996 ton / bulan. Upaya untuk
\end{abstract}


memecahkan masalah ini adalah dengan membuat masyarakat lebih peduli, manajemen limbah, paham aturan, rehabilitasi lahan kritis, tindakan nyata, pengendalian dan tata letak.

Kata kunci: sungai biknoi; limbah domestik; kualitas air; indeks polusi; AHP

\section{Pendahuluan}

Air merupakan sumberdaya alam yang perlu mendapat perlindungan, karena air dibutuhkan oleh semua makhluk hidup, terutama manusia. Hasil survey yang dilakukan Direktorat Pengembangan Air Minum, Ditjen Cipta Karya pada 2006 menunjukkan setiap orang mengkonsumsi air rata-rata sebanyak 144 liter per hari untuk segala kegiatannya.Penggunaan air diperkirakan akan terus meningkat seiring dengan pertumbuhan penduduk (Suripin, 2002).

Perlindungan terhadap air perlu dilakukan, karena adanya permasalahan kuantitas dan kualitas pada air. Pada tahun 2015, diperkirakan kebutuhan air penduduk NTT di musim kemarau akan mengalami minus hingga 37 juta $\mathrm{m}^{3}$ (Suwari 2011). Secara kuantitas air di bumi ini cukup melimpah namun hanya sekitar1 \% dari keseluruhan air yang merupakan air tawar untuk memenuhi kebutuhan manusia (Kudoatie, 2008). Kuantitas air yang mengalami penurunan diakibatkan oleh hilang atau mengeringnya sumber air dan menurunnya kualitas air. Hilang atau mengeringnya sumber air berkaitan dengan peristiwa erosi, sedangkan menurunnya kualitas air dapat disebabkan oleh berbagai buangan limbah dari domestik, industri, pertanian dan kegiatan lainnya sehingga menyebabkan air tercemar (Suwari, 2011).

Kualitas air mencakup keadaan fisik, kimia dan biologi yang dapat mempengaruhi ketersediaan air untuk kehidupan manusia, pertanian, industri, rekreasi dan pemanfaatan air lainnya (Asdak, 2000).Penurunan kualitas air dapat disebabkan oleh beberapa faktor diantaranya karena pencemaran limbah domestik. Permukiman padat di sepanjang sungai cenderung mengakibatkan terhambatnya aliran sungai karena banyaknya sampah domestik yang dibuang ke badan sungai sehingga mengakibatkan berkurangnya daya tampung untuk mengalirkan air yang dating akibat curah hujan yang tinggi di daerah hulu (Suganda,2009). Berdasarkan sumbangan beban pencemaran terhadap kualitas air sungai, aktivitas permukiman memberikan masukan beban pencemaran bahan organik yang paling tinggi (Agustiningsih, 2012).

Limbah domestik yang paling dominan adalah jenis organik yang berupa kotoran manusia dan hewan. Jenis limbah domestik yang lain adalah limbah domestik anorganik yangdiakibatkan oleh plastik serta penggunaan deterjen, sampo, cairan pemutih, pewangi dan bahan kimia lainnya. Limbah domestik jenis ini relatif lebih sulit untuk dihancurkan.Sungai Biknoi merupakan salah satu anak sungai yang terletak di sepanjang wilayah Kelurahan Bakunase II dan Kelurahan Naikolan yang kemudian oleh Pemerintah melalui dinas terkait, dalam hal ini BLHD Kota Kupang dikembangkan pemanfaatannya sebagai sumber baku air bersih PDAM Kota Kupang. Sungai Biknoi melintasi wilayah permukiman sehingga berpotensi mengalami pencemaran oleh limbah domestik.Jumlah penduduk di Kelurahan Bakunase II adalah 5.067 jiwa sedangkan Kelurahan Naikolan 7.507 jiwa. Jumlah KK masing-masing kelurahan adalah 1.119 dan 1.402 KK. Mata pencaharian penduduk bervariasi meliputi PNS, Pensiunan (pegawai negeri dan POLRI), pedagang, petani serta buruh (Laporan bulanan Kelurahan Naikolan dan Kelurahan Bakunase II).

Tujuan dari penelitian ini Mengidentifikasi perilaku penduduk di sekitar Sungai Biknoi dalam membuang limbahdomestik, mengevaluasi kualitas perairan Sungai Biknoi mencakup perubahan beberapa parameter kimia, biologi dan fisika, mengetahui kontribusi limbah domestik penduduk di sekitar Sungai Biknoi, mengetahui upaya 
penanganan yang dapat dilakukan untuk menguranginya dan mengetahui tingkat pencemaran Sungai Biknoi dengan menggunakan metode Indeks Pencemaran.

\section{Metodologi}

Penelitian ini dilaksanakan pada bulan Desember 2013-Januari 2014. Terdapat tiga titik pengambilan sampel yaitu yang pertama berada pada posisi $10^{0} 11$ ' 37 " LS; $135^{\circ} 35^{\prime}$ 54.6" BT. Titik kedua berada pada posisi $10^{0}$ ' 11 ' 29,2" LS; $135^{\circ} 35^{\prime} 55,1^{\prime \prime}$ BT dan titik ketiga berada pada $10^{0} 11^{\prime} 28,0^{\prime \prime}$ LS; $123^{0} 35^{\prime} 55,2$ '”.

Data yang di ambil adalah data mengenai perilaku penduduk dan dan kualitas air Sungai Biknoi yang meliputi fisika, kimia dan biologi. Pengaruh limbah domestik penduduk terhadap air sungai biknoi menggunakan uji chi square. Analisis kualitas air dengan mengacu pada baku mutu yang ditetapkan dalam PP No 82 Tahun 2001. Penentuan status mutu air menggunakan metode indeks pencemaran dengan persamaan 1:

$$
P I_{j}=\sqrt{\frac{\left(C_{i} / L_{i j}\right)_{M}^{2}+\left(C_{i} / L_{i j}\right)_{R}^{2}}{2}}
$$

Tabel 1. Hubungan Nilai Indeks Pencemaran dengan Status Mutu Air

\begin{tabular}{cc}
\hline Indeks pencemaran & Mutu perairan \\
\hline $0 \leq \mathrm{P}_{\mathrm{ij}} \leq 1,0$ & Kondisi baik \\
$1,0<\mathrm{P}_{\mathrm{ij}} \leq 5,0$ & Cemar ringan \\
$5,0<\mathrm{P}_{\mathrm{ij}} \leq 10$ & Cemar sedang \\
\hline $\mathrm{P}_{\mathrm{ij}}>10,0$ & Cemar berat \\
\hline
\end{tabular}

Beban pencemaran dihitung berdasarkan pendekatan Rapid Assessment Of Sources Of Air, Water And Land Pollution dengan memperhatikan faktor konversi beban limbah dari suatu pencemar. Beban pemcemaran limbah domestik dapat diperoleh dengan mengalikan jumlah penduduk dengan faktor konversi yang telah ditentukan.Analisis prioritas terhadap upaya penanggulan pencemaran air sungai biknoi dilakukan dengan wawancara mendalam terhadap 3 k,ey person yang berasal dari instansi yang terkait seperti inas PU Kota Kupang bidang pengairan, BLHD Provinsi NTT, dan Perguruan tinggi.

\section{Hasil dan Pembahasan}

\subsection{Perilaku Penduduk}

Hubungan antara perilaku penduduk dengan kualitas air sungai Biknoi yang di analisis melalui uji Chi square dapat di lihat pada Tabel 2 dibawah:

Tabel 2. Hasil uji Chi Square

\begin{tabular}{cccc}
\hline $\begin{array}{c}\text { Variabel } \\
\text { Independent }\end{array}$ & $\begin{array}{c}\text { Variabel } \\
\text { dependent }\end{array}$ & $\begin{array}{c}\text { Chi Square } \\
\text { Test }\end{array}$ & Keterangan \\
\hline Perilaku & $\begin{array}{c}\text { Kualitas air } \\
\text { bendungan } \\
\text { Biknoi }\end{array}$ & 0,023 & $\begin{array}{c}\text { Ada } \\
\text { hubungan }\end{array}$ \\
\hline
\end{tabular}

Hasil analisis Uji Square menunjukan bahwa terdapat hubungan yang erat antara perilaku penduduk dengan penurunan kualitas air Sungai Biknoi. hasil uji chi square $0,023<0,05$ maka $\mathrm{H}_{0}$ ditolak dan $\mathrm{H}_{1}$ diterima dengan demikian ada hubungan antara perilaku responden baik pengetahuan, sikap dan tindakan dengan kualitas air sungai Biknoi.

\subsection{Kualitas Air Sungai Biknoi}

Dari tiga titik pengambilan sampel, untuk parameter Fecal coli dan minyak lemak telah melampui baku mutu. Nilai parameter yang melampui baku mutu disebabkan oleh pertambahan jumlah penduduk sehingga menyebabkan meningkatnya buangan limbah ke sungai serta tingginya perubahan tutupan lahan akibat konversi lahan menjadi permukiman. 
Maya Roman, dkk. : Kontribusi Limbah Domestik Penduduk di Sekitar Sungai Biknoi .....

Tabel 3. Perhitungan Indeks Pencemaran

\begin{tabular}{ccc}
\hline $\begin{array}{c}\text { Titik } \\
\text { pengambilan } \\
\text { sampel }\end{array}$ & $\begin{array}{c}\text { Indeks } \\
\text { pencemaran air } \\
\text { kelas I }\end{array}$ & Katergori \\
\hline Titik I & 6,12 & Cemar sedang \\
Titik II & 6,31 & Cemar sedang \\
Titik III & 7,11 & Cemar sedang \\
\hline
\end{tabular}

Hasil pengukuran dan analisis tiap parameter dapat menggambarkan kualitas air sungai Biknoi. Keberadaan beberapa parameter yang nilainya melebihi baku mutu menunjukkan kondisi air sungai Biknoi telah mengalami penurunan kualitas sehingga tidak dapat berfungsi sesuai peruntukaannnya.

\subsection{Perhitungan Beban Pencemaran}

Berdasarkan perhitungan beban pencemaran menunjukkan beban pencemaran oleh BOD, COD, TSS dan P-Fosfat tidak memberikan sumbangan yang signifikan terhadap beban pencemaran sungai.Tingginya beban pencemaran disebabkan oleh saluran pembuangan limbah rumah tangga penduduk yang langsung dibuang ke sungai tanpa pengolahan sebelumnya.

Tabel 4. Perhitungan beban pencemaran

\begin{tabular}{|c|c|c|c|c|c|c|c|c|c|}
\hline \multirow{2}{*}{$\begin{array}{c}\text { Titik } \\
\text { Pengambilan }\end{array}$} & \multirow{2}{*}{$\begin{array}{c}\text { Jumlah } \\
\text { Penduduk } \\
\text { (Jiwa) }\end{array}$} & \multicolumn{4}{|c|}{ Faktor Konversi (Kg/Org/Tahun) } & \multicolumn{4}{|c|}{$\begin{array}{c}\text { Potensi Bebn Pencemaran } \\
\text { (Ton/Bulan) }\end{array}$} \\
\hline & & BOD & COD & TSS & P-Fostat & BOD & COD & TSS & P-Fosfat \\
\hline I & 235 & 19.7 & 44 & 20 & 0.4 & 4629.5 & 10340 & 4700 & 94 \\
\hline II & 192 & 19.7 & 44 & 20 & 0.4 & 3782.4 & 8448 & 3840 & 76.8 \\
\hline III & 232 & 19.7 & 44 & 20 & 0.4 & 4570.4 & 10208 & 4640 & 92.8 \\
\hline
\end{tabular}

Sumbangan beban pencemaran terbesar berasal dari parameter COD pada semua titik pengambilan sampel. Parameter BOD dengan potensi beban pencemaran terbesar pada titik I mencapai 4629,5 ton/bulan dan terendah pada titik II dengan nilai mencapai 3782,4 ton/bulan. Angka beban pencemaran terendah pada parameter $\mathrm{P}$ Fosfat dengan nilai 76,8 ton/bulan. Beban pencemaran yang tinggi dari setiap parameter pengukuran sebagai akibat dari aktivitas rumah tangga seperti mandi, cuci dan kakus serta kegiatan beternak oleh penduduk yang menghasilkan limbah yang masuk ke dalam badan air dan menyebabkan pencemaran.

\subsection{Status Mutu Air Sungai}

Perhitungan indeks pencemaran dilakukan pada tiga titik pengambilan dengan tujuh parameter. Baku mutu yang digunakan mengacu pada PP No 82 tahun 2001 tentang pengelolaan kualitas air dan pengendalian pencemaran air.Hasil perhitungan indeks pencemaran menunjukkan air sungai Biknoi berada pada kategori cemar sedang sehingga menurunkan kualitas air dan sekaligus tidak dapat digunakan sesuai peruntukkannnya sebagai sumber baku air minum. Hasil pengukuran terhadap kualitas air sungai Biknoi yang menunjukkan telah mengalami cemar sedang memerlukan upaya pengendalian pencemaran untuk dapat mengembalikan kualitas air agar pemanfaatannya sesuai dengan peruntukkannnya.

\subsection{Upaya Pengendalian Pencemaran Air}

Upaya pengendalian pencemaran air merupakan upaya yang dilakukan dalam rangka pencegahan dan penanggulangan terjadinya pencemaran air serta pemulihan kualitas air sesuai kondisi alaminya sehingga kualitas air sungai terjaga sesuai dengan peruntukkannya.

Strategi pengendalian pencemaran air memerlukan serangkaian kriteria dan alternatif untuk mencapai tujuan yang diinginkan sesuai 
dengan kondisi dan kemampuan sumber daya. Strategi pengendalian pencemaran air dirumuskan berdasarkan wawancara mendalam dengan keyperson serta berdasarkan hasil AHP (Analytical Hierarchy Process) yaitu :

1. Pengelolaan limbah (A1)

2. Rehabilitasi lahan kritis (A2)

3. Penerapan aturan sesuai PERDA yang berlaku (A3)

4. Monitoring atau pengawasan dari pemerintah (A4)

5. Penyuluhan dan sosialisasi diikuti dengan aksi nyata seperti penyediaan tempat sampah gratis dan kerja bakti (A5)

6. Upaya penyadaran masyarakat (A6)

7. Pengaturan tata ruang (A7).
Dari hasil rumusan diatas disusun 4 kriteria utama yang berkaitan dengan strategi pengendalian pencemaran air, yaitu :

1) Aspek efektivitas (K1)

2) Aspek keadilan (K2)

3) Aspek biaya (K3)

4) Aspek partisipasi (K4)

Pendapat para keyperson kemudian di analisis dengan bantuan program expert choice. Hasil analisis adalah sebagai berikut :

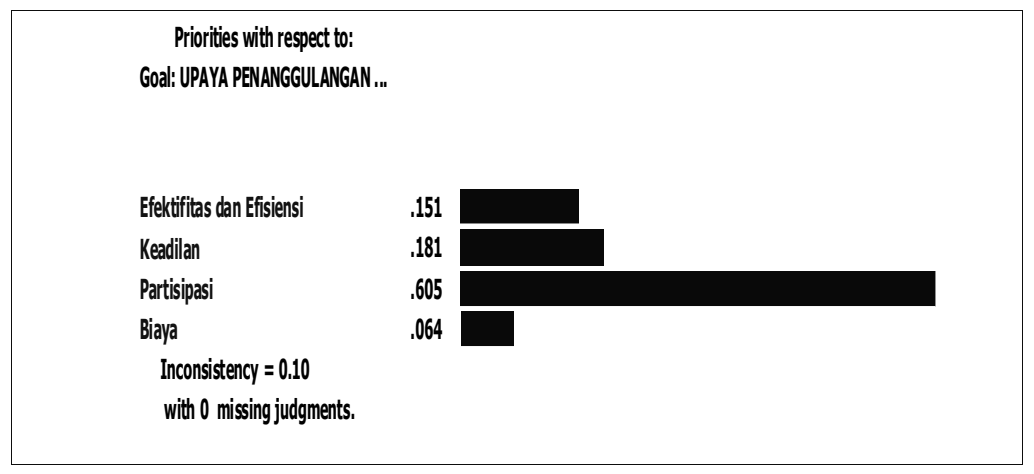

Gambar 1. Analisis Program Expert Choice

Hasil analisis pendapat gabungan para keyperson Hasil analisis pendapat para keyperson yang telah di analisis dengan AHP terhadap upaya penanggulangan pencemaran air menunjukkan bahwa kriteria partisipasi memiliki nilai prioritas paling tinggi sehingga merupakan kriteria yang perlu dikembangkan dalam upaya mengendalikan pencemaran air sungai Biknoi.

Kriteria partisipasi dengan nilai 0,6 dianggap sebagai kriteria yang paling penting dan yang perlu diperhatikan. Kriteria keadilan dengan nilai 0,18 merupakan kriteria terpenting kedua setelah partisipasi. Kriteria yang ketiga adalah kriteria efektifitas dan efisiensi dengan nilai 0,15 dan kriteria yang keempat adalah kriteria biaya dengan niali 0,06. Hasil analisis tersebut memiliki nilai inconsistency adalah 0,10 merupakan batas maksimum sehingga dapat disimpulkan bahwa pendapat para keyperson dan hasil analisa dapat diterima.Hasil analisis alternatif upaya penanggulangan pencemaran air secara keseluruhan dapat dilihat pada tabel 4 yang prioritas lokal kegiatan yang dapat dilakukan dalam upaya pencegahan pencemaran air Sungai Biknoi. Berdasarkan data pada tabel 31, terlihat upaya penyadaran masyarakat mempunyai nilai tertinggi.

Upaya ini dipandang sebagai hal yang paling utama dalam penanggulangan pencemaran air sungai Biknoi. Penyadaran masyarakat 
merupakan hal yang mendasar dan melalui kesadaran dari masyarakat tentang pentingnya menjaga sumber air bersih, dengan sendirinya masyarakat akan berusaha untuk menjaga dan melestarikan sumber air.

Upaya penyadaran masyarakat perlu didukung oleh aksi nyata dari baik dari masyarakat maupun pemerintah.Aksi nyata dapat berupa kerja bakti, penyediaan tempat sampah dan penyuluhan.Alternatif berikut adalah penegakan aturan. Alternatif ini dipandang dapat mengatur serta memberi efek jera.Penegakkan aturan sesuai
PERDA yang berlaku merupakan bentuk upaya yang tegas dan dapat memberi efek jera sehingga dapat menekan atau mengurangi volume limbah rumah tangga yang dibuang ke dalam badan air.Disamping itu diperlukan upaya sosialisasi Undang-Undang Lingkungan Hidup serta peraturan tentang limbah rumah tangga yang berdasarkan hasil wawancara dengan responden masih banyak yang tidak mengetahui adanya Undang-Undang dan Peraturan tersebut. Hasil perbandingan kepentingan alternative berdasarkan kriteria dapat dilihat pada Table 5.

Tabel 5. Hasil perbandingan kepentingan alternative berdasarkan kriteria

\begin{tabular}{|c|c|c|c|c|c|c|c|c|c|c|}
\hline \multirow{2}{*}{ Kriteria } & \multirow{2}{*}{$\lambda$ Maks } & \multirow{2}{*}{$\mathrm{Cl}$} & \multirow{2}{*}{$\mathrm{CR}$} & \multicolumn{7}{|c|}{ Eigen Value } \\
\hline & & & & a1 & $\mathrm{a} 2$ & a3 & $\mathrm{a} 4$ & a5 & a6 & a7 \\
\hline $\begin{array}{c}\text { Efektifitas } \\
\text { dan Efisiensi }\end{array}$ & 7.81 & 0.13 & 0.09 & 5.167 & 5.833 & 8.333 & 8.667 & 8.500 & 9.000 & 13.000 \\
\hline Keadilan & 7.62 & 0.10 & 0.07 & 9.33 & 11.33 & 6.50 & 6.833 & 9.833 & 18.00 & 3.567 \\
\hline Partisipasi & 7.78 & 0.13 & 0.09 & 9.833 & 6.833 & 51.67 & 7.833 & 8.833 & 11.00 & 7.833 \\
\hline Biaya & 7.70 & 0.11 & 0.08 & 10.67 & 4.667 & 10.500 & 5.833 & 7.33 & 17.00 & 6.533 \\
\hline
\end{tabular}

\section{Simpulan dan Saran}

1) Penurunan kualitas air Sungai Biknoi yang disebabkan oleh pembuangan limbah rumah tangga ke dalam badan air. Di temukan beberapa jenis limbah yang berasal dari kegiatan domestik seperti kemasan sabun mandi, kemasan detergen baik yang terbuat dari plastik maupun dari kertas, sisa kemasan makanan dan minuman dan pampers bayi. Selain sampah padat, ditemukan juga sampah atau limbah cair yang berasal dari saluran pembuangan rumah tangga maupun aktifitas MCK dalam badan air.

2) Menurunnya kualitas air sungai berhubungan dengan perilaku (pengetahuan, sikap dan tindakan) penduduk yang bermukim di pinggiran sungai yang memanfaatkan sungai sebagai tempat membuang limbah domestik serta melakukan aktivitas rumah tangga seperti MCK, memandikan ternak dan mencuci kendaraan. Perilaku penduduk dipengaruhi oleh tingkat pendidikan, pekerjaan serta jarak tempat tinggal dengan badan air.

3) Limbah domestik yang dibuang ke dalam sungai baik secara langsung maupun tidak, telah menimbulkan perubahan kualitas air baik dari segi fisik, kimia maupun biologis. Status mutu air sungai yang berada pada kategori cemar sedang mengindikasikan telah terjadi

4) perubahan kualitas air sungai Biknoi yang menyebabkan air sungai Binoi tidak lagi sesuai dengan peruntukannya. 
5) Kontribusi limbah domestik penduduk di sekitar sungai Biknoi telahmenurunkan kualitas air sungai Biknoi Hasil perhitungan potensi beban pencemaran Sungai Biknoi yang terbesar ditunjukkan oleh parameter COD sebesar 28.996 ton/bulan, parameter TSS sebesar 13.180 ton/bulan dan parameter BOD sebesar 12.982 ton/bulan. Beban pencemaran terendah untuk parameter p-fosfat sebesar 263,6 ton/bulan.

6) Perhitungan nilai indeks pencemaran memperlihatkan kondisi status mutu air sungai Biknoi berada pada kategori cemar sedang\ dengan nilai indeks pencemaran berkisar dari 6,12 - 7,11. Berdasarkan Peraturan Pemerintah No. 82 tahun 2001, maka air sungai Biknoi tidak layak digunakan sebagai sumber baku air minum tetapi dapat diperuntukkan penggunaanya untuk mutu air kelas II yaitu air yangperuntukannyadapatdigunakan untukprasarana atau sarana rekreasiair,pembudidayaan ikan air tawar, peternakan, air untukmengairi pertanaman,dan atau peruntukkan lainyang mempersyaratkan mutuairyangsamadengankegunaan tersebut.

7) Upaya pengendalian pencemaran air sungai Biknoi yang penting untuk diperhatikan adalah partisipasi dengan alternatif prioritas upaya penyadaran masyarakat.

\section{Daftar pustaka}

Achmad, Rukaesih. 2004. Kimia Lingkungan. Penerbit Andi, Yogyakarta.

Agustiningsih Dyah, Setia Budi Sasongko, Sudarno. 2012 :Prosiding Seminar Nasional Pengelolaan Sumber Daya Alam dan Lingkungan. Universitas Diponegoro, Semarang.

Asdak, Chay. 2000. Hidrologi dan Pengelolaan Daerah Aliran Sungai. Gadjah Mada University Press, Yogyakarta.
Chandra, Budiman. 2005. Pengantar Kesehatan Lingkungan. Penerbit Buku Kedokteran.

Edward dan M.S Tarigan, 2003 : Kandungan Total Zat Padat Tersuspensi (Total Suspended Solid) Di Perairan Raha, Sulawesi TenggaraJurnal Sains Volume 7 Nomor 3 Desember 2003, halaman 113.

Effendi, Hefni. 2003. Telaah Kualitas Air Bagi Pengelolaan Sumber Daya dan Perairan. Penerbit Kanisius.

Fardiaz, Srikandi. 1992. Polusi Air dan Udara. Penerbit Kanisius.

Hariyadi, R. 2006 : Pengaruh Pencemaran Limbah Industri Dan Domestik Terhadap Kualitas Air Waduk DuriangkangJurnal Teknik Lingkungan ISSN 1441-318X Volume 7 No 3 Hal 271-276.

Hidayatullah, Rakhmat.2010. Populasi Bakteri Eschericia Coli sebagai Indikator Pencemar di Perairan Selat Madura (Studi Kasus antara Perairan Kemal dan Perak Surabaya). Universitas Trunojoyo

Hendrawan, Diana. 2007. Kualitas Air Sungai Ciliwung Ditinjau dari Parameter Minyak dan Lemak JurnalIlmu-Ilmu Perairan dan Perikanan Indonesia, jilid 15 Desember 2008, halaman 85 .

Kartila, 2008.Sikap dan tindakan masyarakat bantaran Sungai Ciliwung dalam Aktivitas Pembuangan Sampah Rumah Tangga, Institut Pertanian Bogor, Bogor.

Kepmen LH No 112 Tahun 2003 Tentang Baku Mutu Air Limbah Domestik.

Kodoatie, Robert. 2008. Pengelolaan Sumber Daya Air Terpadu. Penerbit Andi, Yogyakarta

Notodarmojo, S. 2004. Pencemaran Tanah dan Air. Penerbit ITB, Bandung

Nurmayanti, 2002.Kontribusi Limbah Domestik Terhadap Kualitas Air Kalingarang Semarang. Program Pasca Sarjana Universitas Gajah Mada. Yogyakarta.

Peraturan Pemerintah No 82 tahun 2001 Tentang Pengelolaan Kualitas Air. 
Rohani, Lasma. 2007. Perilaku Masyarakat dalam Pengelolaan Sampah di Desa Medan Senembah Kabupaten Deliserdang dan di Kelurahan Asam Kumbang Kota Medan. Universitas Sumatera Utara.

Saryono dan Anggraeni.2013. Metodologi Penelitian Kualitatif dan Kuantitatif dalam Bidang Kesehatan. Medical Book. Nuha Medika. Yogyakarta.

Sasongko, Lutfi.2006. Kontribusi Air Limbah Domestik Penduduk di Sekitar Sungai Tuk Terhadap Kualitas Air Sungai Kaligarang serta Upaya Penanganannya (Studi Kasus di Kelurahan Sampangan dan Bendan Ngisor Kecamatan Gajah Mungkur, Kota Semarang). Universitas Diponegoro, Semarang.

Setiadi, Amos. 2010. Perilaku Pro Lingkungan pada Permukiman Perkotaan Studi Kasus Pengolahan Sampah di Kampong Sukunan Yogyakarta. Universitas Atmajaya, Yogyakarta.

Setiari, Ni Made. 2012. Identifikasi Sumber Pencemar dan Analisis Kualitas Air Tukad Yeh Sungi di Kabupaten Tabanan dengan Metode Indeks Pencemaran. Universitas Udayana, Denpasar.

Seyhan, Ersin. 1995. Dasar-Dasar Hidrologi. Gadjah Mada University Press, Yogyakarta.

Sosrodarsono, S. 2006. Hidrologi untuk Pengairan. PT Pradnya Paramita, Jakarta

Sudiran, F.L. 2005.Instrumen Sosial Masyarakat Karangmumuskota Samarinda dalam Pengelolaan Sampah Domestik.Makara Sosial Humaniora Volume 9 No. 1 Tahun 2005.

Sugiharti, G. 1997. Faktor-Faktor yang Mempengaruhi Perilaku Sehat Penduduk terhadap Sampah di Kodia Semarang. Program Pasca Sarjana Universitas Gajahmada. Yogyakarta.

Sugiharto, 1987.Dasar-Dasar Pengelolaan Air Limbah, Penerbit Universitas Indonesia, Jakarta.
Suriawiria, Unus. 1996. Air dalam Kehidupan dan Lingkungan yang Sehat. Penerbit Alumni. Bandung.

Suripin, 2002.Pelestarian Sumber Daya Tanah dan Air. Penerbit Andi, Yogyakarta.

Sutikno.Sistem Pendukung Keputusan Metode AHP untuk Pemilihan Siswa dalam Mengikuti Olimpiade Sains di Sekolah Menengah Atas Program Studi Ilmu Komputer FMIPA UNDIP. Universitas Diponegoro, Semarang

Suwari, 2011.Inventarisasi Sumberdaya Air Pulau Timor Propinsi Nusa Tenggara Timur. Pusat Penelitian Lingungan HidupUniversitas Nusa Cendana. Kupang.

Suwari, dkk. 2011. Model Dinamik Pengendalian Pencemaran Air Kali Surabaya. Pusat Penelitian Lingkungan Hidup. Lembaga Penelitian Universitas Udayana, Denpasar.

Suwari, 2011. Media Exacta, Journal Of Science And Enginering. Penentuan Prioritas Kegiatan Reduksi Beban Pencemaran Kali Surabaya Menggunakan Analytical Hierarchy Process. Lembaga Penelitian. Undana.Kupang.

Undang-Undang Republik Indonesia No 7 Tahun 2004 Tentang Sumber Daya Air.

Undang-Undang Republik Indonesia No 32 Tahun 2009 Tentang Lingkungan Hidup.

Wardhana, W.A. 1995. Dampak Pencemaran Lingkungan. Andi Offset. Yogyakarta

Yani, Achmad. Hubungan Kualitas Air dengan Kegiatan Penduduk di Sungai Somber (Studi Kasus : Penurunan Kualitas Air Sungai Somber Bagian Hilir Teluk Balikpapan). Penerbit Universitas Indonesia, Jakarta.

Yuliastuti, Etik. 2011. Kajian Kualitas Air Sungai Ngringo Karanganyar dalam Upaya Pengendalian Pencemaran Air. Universitas Diponegoro, Semarang 